\title{
Interactions Between Herbicide Application and Timing of Nitrogen Fertilization in Maize Hybrids
}

\author{
Guilherme V. Pimentel ${ }^{1}$, Silvino G. Moreira ${ }^{1}$, Mateus O. T. de Avila ${ }^{1}$, Antonio Henrique F. de Carvalho', \\ Alessandro A. P. da Silva ${ }^{1} \&$ Hugo C. de Resende ${ }^{1}$ \\ ${ }^{1}$ Agriculture Department, Federal University of Lavras, Lavras, Minas Gerais, Brazil \\ Correspondence: Guilherme V. Pimentel, Agriculture Department, Federal University of Lavras, Lavras, MG, \\ 37200-000, Brazil. Tel: 55-353-829-1579. E-mail: guilherme.pimentel@ufla.br
}

Received: March 17, 2019

Accepted: April 18, 2019 Online Published: June 30, 2019

doi:10.5539/jas.v11n9p21

URL: https://doi.org/10.5539/jas.v11n9p21

\begin{abstract}
Maize hybrids have different levels of tolerance to the herbicide nicosulfuron, depending on the dose, the environment, the phenological stage of the plant and the timing of nitrogen fertilization, and phytotoxic effects can occur without proper management. There is also limited information on the selectivity of current genetically modified hybrids for other recommended herbicides, such as tembotrione. Thus, the objective of this study was to evaluate the effects of herbicides (tembotrione and nicosulfuron) and the timing of nitrogen fertilization on the yield of maize hybrids. The experimental design was a randomized block design, in a $4 \times 2$ factorial arrangement, with 4 replicates. The treatments consisted of four treatments [weeding; nicosulfuron + atrazine $(20$ and $32+1250$ $\mathrm{g} \mathrm{ha}^{-1}$ ai) and tembotrione + atrazine $\left(75.6+1250 \mathrm{~g} \mathrm{ha}^{-1}\right.$ ai) $)$ and two nitrogen fertilization times $(0$ and 7 days after application). Maize hybrids P30F53 Leptra, DKB 230PRO3 and KWS 9004PRO2 were assessed in two growing seasons $\left(1^{\text {st }}\right.$ and $2^{\text {nd }}$ harvest) during the 2016/2017 growing season. The percentages of weed control; phytotoxicity at 7, 14 and 21 days after application (DAA); plant height; number of rows per ear; and yield at harvest were evaluated. All herbicides were more effective in controlling weeds at the $1^{\text {st }}$ harvest because of favourable climatic conditions. Nitrogen fertilization can be carried out on the same day as the application of the herbicides nicosulfuron and tembotrione with no reduction in yield for the hybrids P30F53 Leptra, DKB 230PRO3 and KWS 9004PRO2.
\end{abstract}

Keywords: selectivity, spikelet, sulfonylureas, Zea mays

\section{Introduction}

With the expansion of no-tillage systems (NTS) in recent years, there has been increased adoption of post-emergence chemical weed control. Thus, the selectivity of the herbicides for maize has become essential. However, there are few herbicide options for post-emergence application and with selectivity for maize. They include glyphosate (in $\mathrm{RR}^{\circledR}$ materials), tembotrione, mesotrione, atrazine and nicosulfuron. The most commonly used are nicosulfuron and tembotrione, combined with atrazine and glyphosate, for glyphosate-resistant hybrids.

For maize, a 7- to 10-day waiting period is recommended between the application of some herbicides and the application of nitrogen fertilizers (Peixoto \& Ramos, 2002; López Ovejero et al., 2003). However, these recommendations are not always followed in the field. In some situations, herbicide and topdressing fertilization are applied on the same day potentially leading to symptoms of phytotoxicity and yield losses.

Currently, for yields above $12 \mathrm{tha}^{-1}$ of maize, hybrids with high productive potential have been used and are fertilized with nitrogen doses of up to $240 \mathrm{~kg} \mathrm{ha}^{-1}$ (Resende et al., 2012). These $\mathrm{N}$ levels are far above the doses tested in several studies on the interaction between herbicides and nitrogen fertilization timing (Nicolai et al., 2006; Guerra et al., 2010; Rodrigues et al., 2012; Souza Jr., 2015). Significant interactions between N fertilization rate and weed control efficiency of herbicides have been observed (Cathcart \& Chandler; Swanton, 2004; Sønderskov, Swanton, \& Kudsk, 2012).

Therefore, the objective of this study was to evaluate the effects of herbicides (tembotrione and nicosulfuron) and nitrogen fertilization timing on the yield of maize hybrids. 


\section{Materials and Methods}

\subsection{Area Description}

The maximum and minimum temperatures during the experimental period $\left(1^{\text {st }}\right.$ and $2^{\text {nd }}$ harvest, 2016/2017 growing season) and the mean rainfall are shown in Figure 1. The maize was grown under an NTS in a Red-Yellow Latosol with clayey texture in different locations. The chemical characterization of the soils of each area and at each harvest at a depth of 0 to $20 \mathrm{~cm}$ is shown in Table 1 .

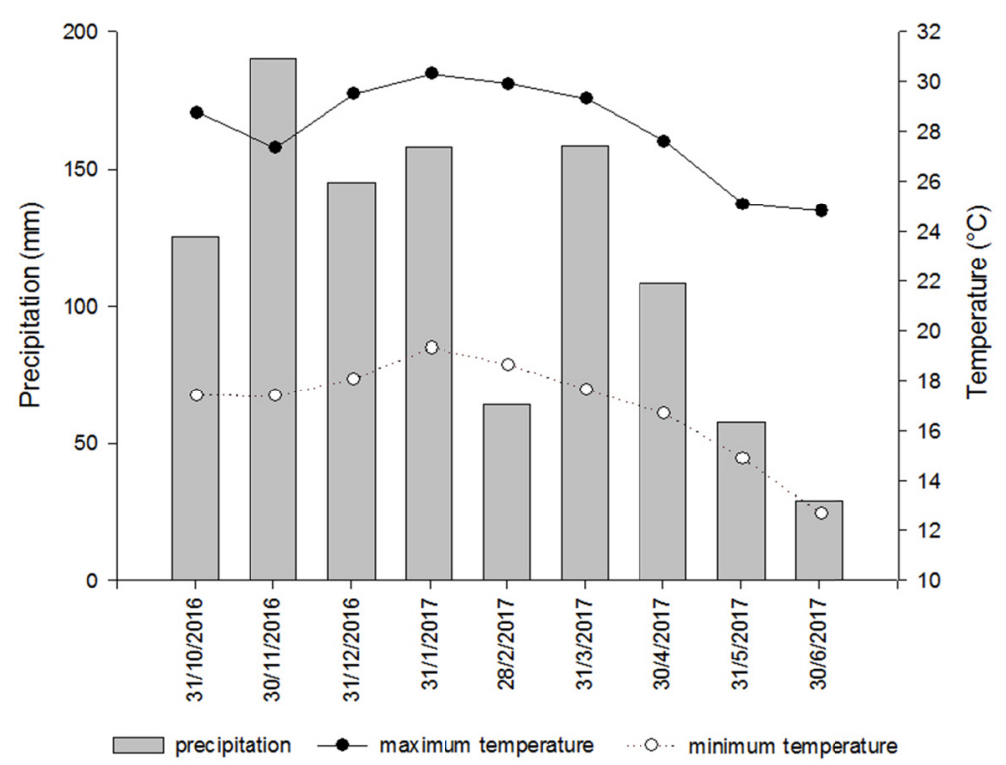

Figure 1. Maximum and minimum temperatures and rainfall in the two experiments $\left(1^{\text {st }}\right.$ and $2^{\text {nd }}$ harvest, 2016/2017 growing season, and $2^{\text {nd }}$ harvest, 2017/2018 growing season)

Source: INMET/BDMEP.

Table 1. Chemical characterization of a typical Red-Yellow Latosol (RYL) at a depth of 0-20 cm

\begin{tabular}{|c|c|c|c|c|c|c|c|c|c|c|}
\hline Season $16 / 17$ & pH & O.M. $^{1}$ & $\mathbf{P}$ & $\mathbf{S}$ & $\mathbf{K}$ & $\mathbf{C a}$ & Mg & Al & $\mathbf{H}+\mathbf{A l}$ & SB \\
\hline & $\mathrm{H}_{2} \mathrm{O}$ & dag $\mathrm{kg}^{-1}$ & \multicolumn{3}{|c|}{----------- $\mathrm{mgdm}^{-3}$---------- } & \multicolumn{5}{|c|}{ 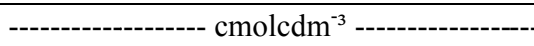 } \\
\hline $1^{\text {st }}$ harvest & 5.8 & 3.1 & $24.1^{2}$ & 11.6 & 48.6 & 3.7 & 0.6 & 0.1 & 4.5 & 4.4 \\
\hline $2^{\text {nd }}$ harvest & 5.7 & - & $4.3^{3}$ & - & 78.2 & 4.5 & 0.8 & 0.1 & 9.8 & 5.5 \\
\hline \multirow[t]{2}{*}{ Season 16/17 } & CEC-t & CEC-T & $\mathbf{V}$ & $\mathbf{m}$ & P-Rem & $\mathbf{Z n}$ & $\mathbf{F e}$ & Mn & $\mathbf{C u}$ & $\mathbf{B}$ \\
\hline & \multicolumn{2}{|c|}{ cmolc dm ${ }^{-3}$} & \multicolumn{2}{|c|}{------- \% ------- } & $\mathrm{mg} \mathrm{L}^{-1}$ & \multicolumn{5}{|c|}{--------------------- $\mathrm{mgdm}^{-3}$---------------- } \\
\hline $1^{\text {st }}$ harvest & 4.5 & 8.9 & 50 & 2 & 29.6 & 2.5 & 65.8 & 13.5 & 0.7 & 0.2 \\
\hline $2^{\text {nd }}$ harvest & 5.6 & 15.3 & 36 & 1 & - & - & - & - & - & - \\
\hline
\end{tabular}

Note. ${ }^{1}$ Organic matter, ${ }^{2} \mathrm{P}-\mathrm{Resin} ;{ }^{3} \mathrm{P}-$ Mehlich-1. $\mathrm{SB}=$ sum of bases; $\mathrm{CEC}=$ cation exchange capability effective (t, at original $\mathrm{pH})$ and at $\mathrm{pH} 7.0(\mathrm{~T}) ; \mathrm{V}=$ base saturation; $\mathrm{m}=$ aluminum saturation; P-Rem = remaining $\mathrm{P}$.

\subsection{Methods and Techniques}

The effects of herbicides combined with nitrogen fertilizer were evaluated on maize hybrids P30F53 (Leptra $\left.{ }^{\circledR}\right)$, DKB 230 (PRO3) and KWS 9004 (PRO2) in two growing seasons ( $1^{\text {st }}$ and $2^{\text {nd }}$ harvest, 2016/2017 growing season). Each maize hybrid constituted a separate experiment.

The experimental design used in the two harvests was a randomized block design (RBD) in a $4 \times 2$ factorial arrangement with 4 replicates. The experimental units consisted of six crop rows, measuring $6 \mathrm{~m}$ in length and spaced $0.6 \mathrm{~m}$ apart, for a total of $21.6 \mathrm{~m}^{2}$. The two central rows were used for data collection and observations excluding the external rows as a border.

There were four weed treatment levels used in the experiment: manual weeding, atrazine + nicosulfuron $(1250+$ $20 \mathrm{~g} \mathrm{ha}^{-1}$ ai), atrazine + nicosulfuron $\left(1250+32 \mathrm{~g} \mathrm{ha}^{-1}\right.$ ai) and atrazine + tembotrione $\left(1250+75.6 \mathrm{~g} \mathrm{ha}^{-1}\right.$ ai) and 
two nitrogen fertilization times: 0 (the same day) and 7 days after application (DAA) of the weed treatments for a total of 32 plots per maize hybrid.

At the first sowing ( $\left(1^{\text {st }}\right.$ harvest: $2016 / 17$ summer $)$, the hybrids were sown on 25 October 2016 with a final density of 75,000 plants ha ${ }^{-1}$ and on 16 February 2017 in the second harvest (off-season) with 60,000 plants ha ${ }^{-1}$.

Fertilization of the crop was based on soil analysis and recommendations for an expected yield of 14 and $9 \mathrm{tha}^{-1}$ for the first and second harvest, respectively, based on Resende et al. (2012). Thus, 435 and $320 \mathrm{~kg} \mathrm{ha}^{-1}$ of NPK 08-28-16 fertilizer were applied to the sowing furrow; in the pre-sowing period, 70 and $30 \mathrm{~kg} \mathrm{ha}^{-1}$ of $\mathrm{K}_{2} \mathrm{O}$ were applied by broadcasting over the entire area; and 175 and $95 \mathrm{~kg} \mathrm{ha}^{-1}$ of $\mathrm{N}$ as topdressing (using urea as $\mathrm{N}$ source) in the V4 stage (four fully expanded leaves) were applied over the entire area, for the first and second harvests, respectively.

Pests and diseases were controlled during the experiment, based on the technical recommendations for the crop, using the insecticides Engeo Pleno ${ }^{\circledR}\left(250 \mathrm{~mL} \mathrm{ha}^{-1}\right)$ and Brilhante $\mathrm{BR}^{\circledR}\left(600 \mathrm{~mL} \mathrm{ha}^{-1}\right)$ and the fungicide Fox ${ }^{\circledR}(500$ $\left.\mathrm{mL} \mathrm{ha}{ }^{-1}\right)+$ Aúreo $^{\circledR}(0.25 \%)$. When the crop was between the phenological stages V5-V6, micronutrients of the Kellus Inox ${ }^{\circledR}$ formula $\left(400 \mathrm{~g} \mathrm{ha}^{-1}\right)$ were applied to the leaves using a spray volume of $200 \mathrm{~L} \mathrm{ha}^{-1}$.

The herbicide treatments were applied with a $\mathrm{CO}_{2}$ pressurized backpack sprayer equipped with four TT110015 fan spray nozzles, spaced $0.5 \mathrm{~m}$ apart. The application volume used was $200 \mathrm{~L} \mathrm{ha}^{-1}$ with a working pressure of 1.8 bar. The applications were done in the morning because of the milder temperatures to avoid the loss of the product by evaporation. All treatments were applied post-emergence when the maize plants were in the V4 phenological stage.

Weed control evaluations and species identification were performed at 0, 7, 14 and 21 days after application (DAA) of the treatments. Two frames with an area of $0.25 \mathrm{~m}^{2}$ were placed randomly in each plot to calculate the density of individuals in the population, expressed as number of plants $\mathrm{m}^{-2}$.

To evaluate the percentage control of the treatments at 7, 14 and 21 DAA, the number of weeds $\mathrm{m}^{-2}$ was compared to the number of weeds at 0 DAA in all plots.

Phytotoxicity was evaluated by assigning plant toxicity scores based on the visual identification of damage in the maize crop at 7, 14 and 21 days after herbicide application (DAA). The scores represented the mean of four replicates and were assigned based on the European Weed Research Council (EWRC, 1964) rating scale, as adapted by Melhorança (1984), where 1 = no damage; 2 = small changes (discolouration, deformation) visible in some plants; $3=$ small changes (discolouration, deformation) visible in many plants; $4=$ strong discolouration (yellowing) or deformation without necrosis (tissue death); $5=$ necrosis (burning) of some leaves, especially on the margins, accompanied by deformation of leaves; $6=$ more than $50 \%$ of the leaves exhibiting necrosis (deformation); $7=$ more than $80 \%$ of the leaves destroyed; $8=$ extremely severe damage, leaving only small green areas on the plants; and $9=$ plant death.

The effects of phytotoxicity on maize growth were determined by measuring the height of maize plants at the phenological stage VT. Height was measured from the root crown to the base of the flowering panicle in five randomly selected plants per plot.

At the time of harvest, five ears of corn were randomly collected in each plot to evaluate the number of rows per ear (NF). The yield was estimated by harvesting the two central rows of each plot, where the ears were mechanically threshed to separate the grains, which were weighed. Then, the moisture of each sample was measured to correct the total grain weight per plot to $13 \%$ moisture.

Initially, individual analyses of variance were performed using the F test for the experiments. Subsequently, a combined analysis was conducted for the two harvests for each hybrid. Finally, the means of the experiments were analysed using the Scott-Knott test at 5\% probability using the SISVAR statistical programme (Ferreira, 2011).

\section{Results and Discussion}

In the $1^{\text {st }}$ and $2^{\text {nd }}$ harvests (2016/17 growing season), the natural weed community in the maize crop was composed of southern sandbur (Cenchrus echinatus), littlebell (Ipomoea triloba), Benghal dayflower (Commelina benghalensis), hairy beggarticks (Bidens pilosa), gallant soldier (Galinsoga parviflora) and others (several species with abundance below 5\% each). Of the predominant species, two are monocots, the southern sandbur and Benghal dayflower, and three are eudicots, littlebell, hairy beggarticks and gallant soldier. In the experimental area of both harvests, C. echinatus was dominant followed by $C$. benghalensis and I. triloba at 0 DAA, covering more than $77 \%$ of the total area (Figure 2). 

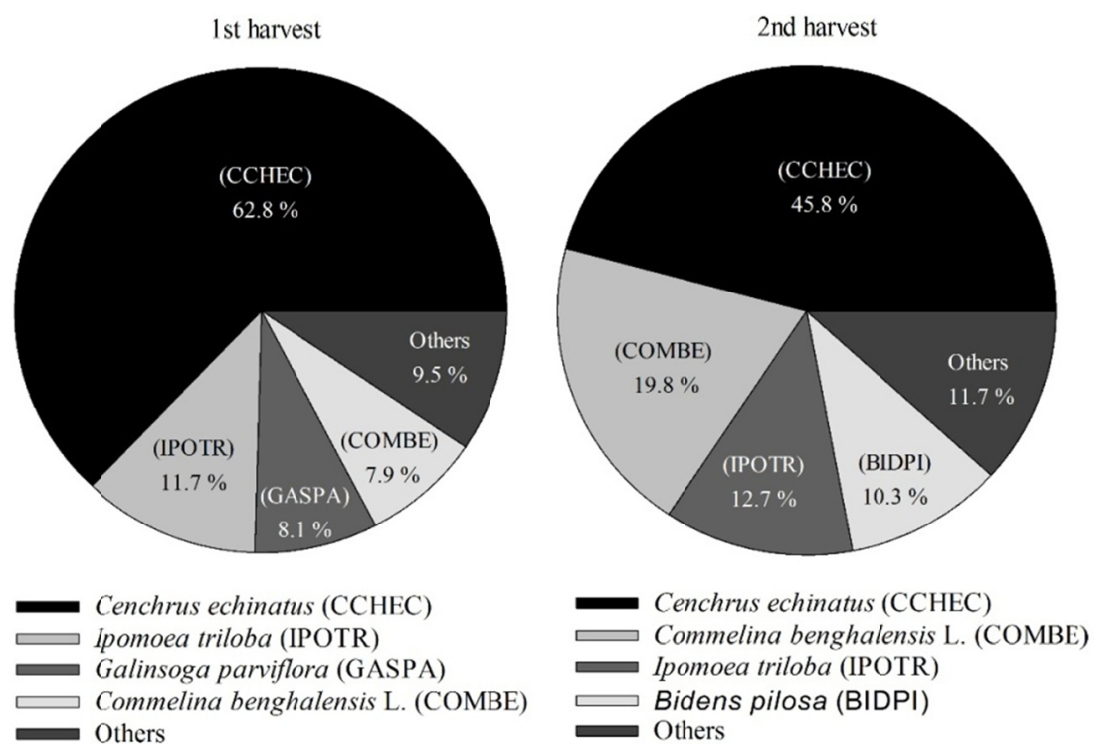

Figure 2. Percentage of weeds at 0 days after application of the control treatments, $1^{\text {st }}$ and $2^{\text {nd }}$ harvests

From the analysis of variance, weed control in the experimental area of both harvests differed significantly $(\mathrm{p}<$ 0.05 ) between treatments at 14 and 21 days after application (DAA) of control treatments, and there were no significant differences $(\mathrm{p}>0.05)$ at 7 DAA.

The percentage of weed control was more efficient in the $1^{\text {st }}$ harvest than in the $2^{\text {nd }}$ harvest in all evaluations (Table 2). The highest weed control efficiency of the herbicide occurred in the 1 st harvest owing to adequate water conditions at that sowing time, where the rainfall accumulation from sowing until the application of the herbicides was $161.3 \mathrm{~mm}$ and $59.8 \mathrm{~mm}$ for the $1^{\text {st }}$ and $2^{\text {nd }}$ harvests, respectively. Under favourable water conditions $\left(1^{\text {st }}\right.$ harvest), herbicides are more easily absorbed and translocated in plants. In contrast, under stress or dry conditions ( $2^{\text {nd }}$ harvest), weeds may undergo morphological changes, such as leaf cuticle dehydration, which may reduce herbicide absorption, as well as the phytotoxicity and effectiveness of the product for weed control (Peregoy et al., 1990). According to Kramer (1987), in plants cultivated under water deficit conditions, the translocation of water and other substances is also compromised, since there is a reduction in transpiration and, consequently, in mass flow, which hinders the transport of the herbicide to its site of action in the plant cell.

Table 2. Percentage control and number of weeds $\left(\mathrm{m}^{2}\right)$ in the control treatments. Means followed by the same uppercase letter in the row and lowercase in the column do not statistically differ at a $5 \%$ probability level with the Scott-Knott test

\begin{tabular}{|c|c|c|c|c|c|c|c|c|}
\hline \multirow{2}{*}{\multicolumn{3}{|c|}{ Treatment }} & \multicolumn{6}{|c|}{ Harvest } \\
\hline & & & \multicolumn{2}{|c|}{$7 \mathbf{D A A}^{1}$} & \multicolumn{2}{|c|}{14 DAA } & \multicolumn{2}{|c|}{21 DAA } \\
\hline Nicosulfuron & Atrazine & Tembotrione & $1^{\mathrm{st}}$ & $2^{\text {nd }}$ & $1^{\text {st }}$ & $2^{\text {nd }}$ & $1^{\text {st }}$ & $2^{\text {nd }}$ \\
\hline \multicolumn{3}{|c|}{ 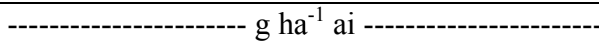 } & ----- & -------- & ------ C & trol $(\%)$ & ---------- & 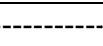 \\
\hline \multicolumn{3}{|c|}{ No herbicides (weeding) } & $100 \mathrm{a}$ & $100 \mathrm{a}$ & $100 \mathrm{Aa}$ & $100 \mathrm{Aa}$ & $100 \mathrm{Aa}$ & $100 \mathrm{Aa}$ \\
\hline 20 & 1250 & - & $42 \mathrm{a}$ & $29 \mathrm{a}$ & $76 \mathrm{Ab}$ & $16 \mathrm{Bc}$ & $72 \mathrm{Ac}$ & $0 \mathrm{Bb}$ \\
\hline 32 & 1250 & - & $47 \mathrm{a}$ & $34 \mathrm{a}$ & $86 \mathrm{Ab}$ & $31 \mathrm{Bb}$ & $89 \mathrm{Ab}$ & $3 \mathrm{Bb}$ \\
\hline- & 1250 & 75.6 & $76 \mathrm{a}$ & $60 \mathrm{a}$ & $91 \mathrm{Aa}$ & $27 \mathrm{Bb}$ & $88 \mathrm{Ab}$ & $5 \mathrm{Bb}$ \\
\hline \multicolumn{3}{|l|}{ Environment } & $66 \mathrm{~A}$ & $56 \mathrm{~B}$ & $88 \mathrm{~A}$ & $44 \mathrm{~B}$ & $87 \mathrm{~A}$ & $27 \mathrm{~B}$ \\
\hline \multicolumn{3}{|l|}{$\mathrm{CV}(\%)$} & 43 & & 33 & & 29 & \\
\hline
\end{tabular}

Note. 'DAA: days after application.

The unfavourable environmental conditions of the $2^{\text {nd }}$ harvest may have reduced the growth and closing of the canopy of the maize crop, allowing the entry of light and increasing the competition of the weed community, which would reduce the weed control efficacy. Thus, the mean number of weeds $\mathrm{m}^{-2}$ increased from 72.8 to 171.2 from 
sowing to 21 DAA in the $2^{\text {nd }}$ harvest (Table 3), an increase of $235 \%$, demonstrating the importance of the water conditions in the management of weeds and in the canopy closure of the maize crop.

Table 3. Number of weeds in $1 \mathrm{~m}^{2}$ (No. W.) in the control treatments. Means followed by the same uppercase letter in the row and lowercase in the column do not statistically differ at a 5\% probability level with the Scott-Knott test

\begin{tabular}{|c|c|c|c|c|c|c|}
\hline \multirow{2}{*}{\multicolumn{3}{|c|}{ Treatment }} & \multicolumn{4}{|c|}{ Harvest } \\
\hline & & & \multicolumn{2}{|c|}{$0 \mathbf{D A A}^{1}$} & \multicolumn{2}{|c|}{21 DAA } \\
\hline Nicosulfuron & Atrazine & Tembotrione & $1^{\text {st }}$ & $2^{\text {nd }}$ & $\mathbf{1}^{\text {st }}$ & $2^{\text {nd }}$ \\
\hline \multicolumn{3}{|c|}{----------------------- g ha'1 ai --------------------- } & \multicolumn{4}{|c|}{ - } \\
\hline \multicolumn{3}{|c|}{ No herbicides (weeding) } & \multirow{4}{*}{110.7} & \multirow{4}{*}{72.8} & $0.0 \mathrm{Aa}$ & $0.0 \mathrm{Aa}$ \\
\hline 20 & 1250 & - & & & $29.7 \mathrm{Ab}$ & $301.2 \mathrm{Bc}$ \\
\hline 32 & 1250 & - & & & $9.8 \mathrm{Ab}$ & $210.2 \mathrm{Bb}$ \\
\hline- & 1250 & 75.6 & & & $8.3 \mathrm{Ab}$ & $173.3 \mathrm{Bb}$ \\
\hline \multicolumn{3}{|l|}{ Environment } & & & $12.0 \mathrm{~B}$ & $171.2 \mathrm{~A}$ \\
\hline \multicolumn{3}{|l|}{$\mathrm{CV}(\%)$} & \multicolumn{4}{|c|}{55} \\
\hline
\end{tabular}

Note. ${ }^{1} \mathrm{DAA}$ : days after application.

For control treatments, in the $1^{\text {st }}$ harvest at 14 DAA, the treatment with tembotrione + atrazine $\left(75.6+1250 \mathrm{~g} \mathrm{ha}^{-1}\right.$ ai) did not differ from the control (weeding) with a percentage control of $91 \%$ (Table 2). At 21 DAA, the herbicides nicosulfuron + atrazine $\left(32+1250 \mathrm{~g} \mathrm{ha}^{-1}\right.$ ai) and tembotrione + atrazine $\left(75.6+1250 \mathrm{~g} \mathrm{ha}^{-1}\right.$ ai) were effective in controlling the weed community with a percentage control of more than $88 \%$. For the $2^{\text {nd }}$ harvest, herbicide was not effective, with low percentage control, owing to the adverse environmental conditions mentioned above.

For analysis of the percentage control with nitrogen fertilization times (Table 4), there were significant differences $(\mathrm{p}<0.05)$ in the evaluations at 7 and 14 DAA. However, at the end of the evaluation at 21 DAA, regardless of the nitrogen fertilization time (0 or 7 DAA), the percentage control and number of weeds $\left(\mathrm{m}^{2}\right)$ did not differ statistically.

Table 4. Percentage control at 7, 14 and 21 days after application (DAA) with nitrogen fertilization times at 0 DAA and 7 DAA. Means followed by the same letter in the column do not differ statistically at a 5\% probability level with the Scott-Knott test

\begin{tabular}{|c|c|c|c|c|}
\hline N time ${ }^{1}$ & 7 DAA & 14 DAA & 21 DAA & 21 DAA \\
\hline & \multicolumn{3}{|c|}{--------------------- (\%) Control -------------------- } & No. W. $\left(\mathrm{m}^{2}\right)^{2}$ \\
\hline 0 DAA & $65 \mathrm{a}$ & $62 \mathrm{~b}$ & $56 \mathrm{a}$ & $100 \mathrm{a}$ \\
\hline 7 DAA & $57 \mathrm{~b}$ & $70 \mathrm{a}$ & $59 \mathrm{a}$ & $83 \mathrm{a}$ \\
\hline $\mathrm{CV}(\%)$ & 43 & 33 & 29 & 55 \\
\hline
\end{tabular}

Note. ${ }^{1} \mathrm{~N}$ time: topdressing nitrogen fertilization time. ${ }^{2}$ No. $\mathrm{W} .\left(\mathrm{m}^{2}\right)$ : number of weeds in $1 \mathrm{~m}^{2}$.

The results obtained in this study indicate that the timing of nitrogen fertilization does not interfere with weed control at the end of the evaluation, regardless of the control treatment used and the harvests (Table 4). Therefore, for weed control in maize crops with the hybrids 30F53, DKB 230 and KWS 9004, the herbicides nicosulfuron, up to a dose of $32 \mathrm{~g} \mathrm{ha}^{-1}$ ai, or tembotrione $\left(75.6 \mathrm{~g} \mathrm{ha}^{-1} \mathrm{ai}\right)$, combined with atrazine, can be applied on the same day as nitrogen fertilization.

Many studies on the effect of nitrogen fertilization on the diversity of weed species have been carried out with varying N doses (Cathcart, Chandler, \& Swanton, 2004; Kim et al., 2006; Zanatta et al., 2007; Brosnan et al., 2010; Sønderskov, Swanton, \& Kudsk, 2012). For example, Zanatta et al. (2007) used nicosulfuron + atrazine $(32+1200$ $\left.\mathrm{g} \mathrm{ha}^{-1} \mathrm{ai}\right)$ and analysed the effect of nitrogen $\left(0,50,100,150\right.$ and $\left.200 \mathrm{~kg} \mathrm{ha}^{-1}\right)$ and the weed control time in maize (V2, V3, V4 and V5). They observed that high doses of nitrogen, together with the controls carried out later, minimized the negative effect of weeds on the crop. Similar results were observed by Cathcart et al. (2004), who showed that the availability of nitrogen to the plants affected the control of some weed species. Plants with higher $\mathrm{N}$ availability were more easily controlled by herbicides. 
In the present study, $\mathrm{N}$ doses applied to the soil were high in both harvests $\left(200 \mathrm{~kg} \mathrm{~N}^{-1}{ }^{-1}\right.$ in the $1^{\text {st }}$ harvest and 120 $\mathrm{kg} \mathrm{N} \mathrm{ha}^{-1}$ in the $2^{\text {nd }}$ harvest). Thus, irrespective of $\mathrm{N}$ application time, high doses may contribute to increased metabolic activity of weeds, increasing the efficacy of the herbicides (Medauar et al., 2018). However, the mechanisms responsible for the greater efficacy of herbicides applied to plants under greater nitrogen availability conditions are not yet well understood. For nicosulfuron, the action of the herbicide occurred in the post-emergence period with rapid absorption and translocation to the meristematic and developing tissue regions, where the ALS enzyme is more active (Peterson et al., 2015; Jakelaitis et al., 2006). Therefore, conditions that favour the growth and development of weeds may also increase the translocation of nicosulfuron, contributing to the greater efficacy of the product.

According to the analysis of variance, there are significant differences in the combined analyses for the traits plant height, number of rows per ear and yield of hybrids. For plant height, there were significant differences between environments, i.e., maize hybrids had greater heights in the $1^{\text {st }}$ harvest (mean of $2.6 \mathrm{~m}$ ) than in the $2^{\text {nd }}$ harvest (mean of $2.3 \mathrm{~m}$ ), which was expected owing to the better soil and climatic conditions at the $1^{\text {st }}$ harvest.

For the number of rows per ear, only hybrid P30F53 was affected by weed control treatments $(p<0.05)$ (Table 5$)$. However, these were small differences with very little practical impact.

Table 5. Effect of weed control treatment on number of rows per ear for hybrids KWS 9004, P30F53 and DKB 230. Means followed by the same letter in the column do not differ statistically at a $5 \%$ probability level with the Scott-Knott test

\begin{tabular}{|c|c|c|c|c|c|}
\hline \multicolumn{3}{|c|}{ Treatments } & \multicolumn{3}{|c|}{ Number of rows } \\
\hline Nicosulfuron & Atrazine & Tembotrione & KWS 9004 & P30F53 & DKB 230 \\
\hline \multicolumn{3}{|c|}{ No herbicides (weeding) } & $16.2 \mathrm{a}$ & $16.0 \mathrm{~b}$ & $15.5 \mathrm{a}$ \\
\hline $20^{1}$ & 1250 & - & $16.0 \mathrm{a}$ & $15.6 \mathrm{a}$ & $15.6 \mathrm{a}$ \\
\hline 32 & 1250 & - & $16.4 \mathrm{a}$ & $16.2 \mathrm{~b}$ & $15.2 \mathrm{a}$ \\
\hline - & 1250 & 75.6 & $17.9 \mathrm{a}$ & $15.9 \mathrm{~b}$ & $15.5 \mathrm{a}$ \\
\hline \multicolumn{3}{|l|}{ General Media } & 16.6 & 15.4 & 15.4 \\
\hline \multicolumn{3}{|l|}{ CV $(\%)$} & 16 & 4 & 4 \\
\hline
\end{tabular}

Note. ${ }^{1} \mathrm{~g} \mathrm{ha}{ }^{-1}$ ai.

In the studies by López Ovejero et al. (2003), the number of rows per ear was not affected by the application of the herbicide nicosulfuron (doses of 20 and $40 \mathrm{~g} \mathrm{ha}^{-1}$ ai) applied to P3027 maize with four fully expanded leaves (V4). In contrast, when the herbicide was applied to maize with eight fully expanded leaves using doses of 40 and $52 \mathrm{~g}$ $\mathrm{ha}^{-1}$ ai, there were reductions in the number of rows. Similar results were found by Fancelli et al. (1998), who demonstrated that in phenological stages V4-V6, the vegetative phase of the apical meristem ends and differentiation of the male inflorescence primordia (tassel) occurs. Later, in the V7-V9 stages, flower bud (spikelet) differentiation begins; immediately after this differentiation, the number of rows per ear and the number of grains per row that will make up the future ear are rapidly determined (Andrade et al., 1996).

In the mean of all control treatments, all hybrids showed higher yields in the first harvest (Table 6), which was expected owing to the better climatic conditions of the first harvest (Figure 1), as well as the higher fertilizer doses used. The yields of hybrids KWS 9004 and DKB 230 in the two harvests and of 30F53 in the first harvest were not statistically affected by herbicide application. 
Table 6. Mean yield of hybrids KWS 9004, P30F53 and DKB230 in the two harvests of 2016/17. Means followed by the same uppercase letter in the row and lowercase in the column do not differ statistically at a $5 \%$ probability level with the Scott-Knott test

\begin{tabular}{|c|c|c|c|c|c|c|c|c|}
\hline \multicolumn{3}{|c|}{ Treatments } & \multicolumn{2}{|c|}{ KWS 9004} & \multicolumn{2}{|c|}{ P30F53 } & \multicolumn{2}{|c|}{ DKB 230} \\
\hline Nicosulfuron & Atrazine & Tembotrione & $\mathbf{1}^{\text {st }}$ & $2^{\text {nd }}$ & $\mathbf{1}^{\text {st }}$ & $2^{\text {nd }}$ & $1^{\text {st }}$ & $2^{\text {nd }}$ \\
\hline \multicolumn{3}{|c|}{ 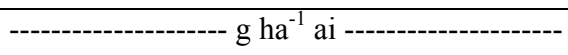 } & \multicolumn{6}{|c|}{ - } \\
\hline \multicolumn{3}{|c|}{ No herbicides (weeding) } & $13290 \mathrm{Aa}$ & $8746 \mathrm{Ba}$ & $13714 \mathrm{Aa}$ & $9927 \mathrm{Ba}$ & $13907 \mathrm{Aa}$ & $8200 \mathrm{Ba}$ \\
\hline 20 & 1250 & - & $13170 \mathrm{Aa}$ & $8602 \mathrm{Ba}$ & $14598 \mathrm{Aa}$ & $8995 \mathrm{Bb}$ & $13025 \mathrm{Aa}$ & $7885 \mathrm{Ba}$ \\
\hline 32 & 1250 & - & $13328 \mathrm{Aa}$ & $7920 \mathrm{Ba}$ & $14192 \mathrm{Aa}$ & $10150 \mathrm{Ba}$ & $13943 \mathrm{Aa}$ & $6993 \mathrm{Ba}$ \\
\hline- & 1250 & 75.6 & $14130 \mathrm{Aa}$ & $7936 \mathrm{Ba}$ & $14497 \mathrm{Aa}$ & $8744 \mathrm{Bb}$ & $13474 \mathrm{Aa}$ & $6990 \mathrm{Ba}$ \\
\hline \multicolumn{3}{|l|}{ Environment } & $13477 \mathrm{~A}$ & $8301 \mathrm{~B}$ & $14250 \mathrm{~A}$ & $9454 \mathrm{~B}$ & $13587 \mathrm{~A}$ & $7517 \mathrm{~B}$ \\
\hline \multicolumn{3}{|l|}{ General Media } & \multicolumn{2}{|l|}{10889} & \multicolumn{2}{|l|}{11852} & \multicolumn{2}{|l|}{10552} \\
\hline \multicolumn{3}{|l|}{ CV (\%) } & \multicolumn{2}{|l|}{15} & \multicolumn{2}{|l|}{9} & \multicolumn{2}{|l|}{9} \\
\hline
\end{tabular}

In the $2^{\text {nd }}$ harvest, the application of nicosulfuron $\left(20 \mathrm{~g} \mathrm{ha}^{-1}\right.$ ai) or of tembotrione ( $75.6 \mathrm{~g} \mathrm{ha}^{-1}$ ai), combined with atrazine (1250 $\mathrm{g} \mathrm{ha}^{-1}$ ai), decreased P30F53 yield compared to the control treatment and the application of nicosulfuron at the highest dose $\left(32 \mathrm{~g} \mathrm{ha}^{-1}\right.$ ai) + atrazine (Table 6). Such differences could suggest restrictions on the recommendation of these herbicides for the hybrid P30F53. However, no phytotoxic effect was observed for the hybrids tested. Thus, other abiotic factors may have caused this effect, since the higher dose of nicosulfuron (32 $\mathrm{g} \mathrm{ha}^{-1} \mathrm{ai}$ ) did not cause a reduction in hybrid yield.

In the treatment with tembotrione + atrazine $\left(75.6+1250 \mathrm{~g} \mathrm{ha}^{-1}\right.$ ai), a negative effect on yield was also not expected. Karam et al. (2009) observed a phytotoxic effect of tembotrione ( 80 and $100 \mathrm{~g} \mathrm{ha}^{-1}$ ai) on BRS 1030 , DKB 393A, DOW 2A525, P30F53 and SPEED hybrids, but no significant difference in grain yield was observed. Selectivity to tembotrione was also observed by Spader et al. (2008) in several maize hybrids, including P30F53.

For the hybrid P30F53, we found a significant interaction $(\mathrm{p}<0.05)$ between weed control treatments and nitrogen fertilization times (Table 7). However, this interaction was observed only when weeding was performed manually. For the herbicide treatments, there were no differences for nitrogen fertilization at 0 or 7 DAA. Weeding may have accelerated the decomposition of crop remains and the use of $\mathrm{N}$ present in the soil by microorganisms. As topdressing nitrogen was applied only 7 days after weeding, there may have been temporary competition for soil $\mathrm{N}$ between the decomposing microorganisms and the maize plants.

Table 7. Mean yield of the hybrid P30F53 as a function of weed control treatments and nitrogen fertilization times. Means followed by the same uppercase letter in the row and lowercase in the column do not differ statistically at a $5 \%$ probability level with the Scott-Knott test

\begin{tabular}{|c|c|c|c|c|}
\hline \multicolumn{3}{|c|}{ Treatments } & \multicolumn{2}{|c|}{ P30F53 } \\
\hline Nicosulfuron & Atrazine & Tembotrione & O DAA ${ }^{1}$ & 7 DAA \\
\hline \multicolumn{3}{|c|}{ - } & \multicolumn{2}{|c|}{ - } \\
\hline \multicolumn{3}{|c|}{ no herbicides (weeding) } & $12707 \mathrm{Aa}$ & $10933 \mathrm{Ba}$ \\
\hline $20^{1}$ & 1250 & - & $11831 \mathrm{Aa}$ & $11761 \mathrm{Aa}$ \\
\hline 32 & 1250 & - & $12045 \mathrm{Aa}$ & $12297 \mathrm{Aa}$ \\
\hline- & 1250 & 75.6 & $11296 \mathrm{Aa}$ & $11945 \mathrm{Aa}$ \\
\hline \multicolumn{3}{|l|}{ General Media } & \multicolumn{2}{|l|}{11852} \\
\hline \multicolumn{3}{|l|}{ CV (\%) } & \multicolumn{2}{|l|}{9} \\
\hline
\end{tabular}

Note. ${ }^{1} \mathrm{DAA}$ : days after application.

\section{Conclusions}

All herbicides were more effective in weed control in the $1^{\text {st }}$ harvest than in the $2^{\text {nd }}$ harvest owing to favourable climatic conditions.

Nitrogen fertilization can be carried out on the same day as the application of the herbicides nicosulfuron (up to 32 $\mathrm{g} \mathrm{ha}^{-1}$ ai) and tembotrione ( $75 \mathrm{~g} \mathrm{ha}^{-1}$ ai) with no reduction in yield for maize hybrids KWS 9004, DKB 230 and P30F53. 


\section{References}

Andrade, F. H., Cirilo, A. G., Uhart, S. A., \& Otegui, M. E. (1996). Ecofisiología del cultivo de maiz (No. 633.15 584.92041). Dekalb Press.

Brosnan, J. T., Thoms, A. W., McCullough, P. E., Armel, G. R., Breeden, G. K., Sorochan, J. C., \& Mueller, T. C. (2010). Efficacy of flazasulfuron for control of annual bluegrass (Poa annua) and perennial ryegrass (Lolium perenne) as influenced by nitrogen. Weed Science, 58, 449-456. https://doi.org/10.1614/ WS-D-09-00019.1

Cathcart, R. J., Chandler, K., \& Swanton, C. J. (2004). Fertilizer nitrogen rate and the response of weeds to herbicides. Weed Science, 52, 291-296. https://doi.org/10.1614/WS-03-049R

EWRC (European Weed Research Council). (1964). Report of the 3th and 4th meetings of EWRC-Committee of methods in weed research. Weed Research, 4, 88.

Fancelli, A. L., Ovejero, R. F., Dourado Neto, D., \& Vocurca, H. (1998). Influência do uso de herbicidas no rendimento e nos componentes de produção de milho. Globalização e Segurança Alimentar, Resumos.

Ferreira, D. F. (2011). Sisvar: A computer statistical analysis system. Ciência e Agrotecnologia, 35, $1039-1042$. https://doi.org/10.1590/S1413-70542011000600001

Guerra, N., Maciel, C. D. G., Oliveira Neto, A. M., Poletine, J. P., Lima, G. G. R., \& Júnior, L. C. S. (2010). Seletividade de formulações de nicosulfuron para híbridos de milho em função da época da adubação nitrogenada. Revista Brasileira de Herbicidas, 9, 89-99. https://doi.org/10.7824/rbh.v9i3.86

Jakelaitis, A., Silva, A. A., Silva, A. F., Silva, L. L., Ferreira, L. R., \& Vivian, R. (2006). Efeitos de herbicidas no controle de plantas daninhas, crescimento e produção de milho e Brachiaria brizantha em consórcio. Pesquisa Agropecuária Tropical, 36, 53-60. https://doi.org/10.5216/pat.v36i1.2172

Karam, D. K., Silva, J. A. A., Pereira Filho, I. A., \& Magalhães, P. C. (2009). Características do herbicida tembotrione na cultura do milho (No. 129). Sete Lagoas: Embrapa Milho e Sorgo, Circular Técnica. Retrieved from https://core.ac.uk/download/pdf/15429334.pdf

Kim, D. S., Marshall, E. J. P., Caseley, J. C., \& Brain, P. (2006). Modelling interactions between herbicide and nitrogen fertiliser in terms of weed response. Weed Research, 46, 480-491. https://doi.org/10.1111/ j.1365-3180.2006.00531.x

Kramer, P. J. (1987). Water relations of plants (p. 489). London: Academic Press.

López Ovejero, R. F., Christoffoleti, P. J., Nicolai, M., \& Barela, J. F. (2003). Manejo de plantas daninhas na cultura do milho. Milho: Estratégias de manejo para alta produtividade (pp. 47-79). Piracicaba: ESALQ/USP/LPV.

Medauar, C. C., Silva, S. D. A., Carvalho, L. C. C., Tibúrcio, R. A. S., Lima, J. S. D. S., \& Medauar, P. A. S. (2018). Monitoring of eucalyptus sprouts control using digital images obtained by unmanned aerial vehicle. Journal of Sustainable Forestry, 37, 739-752. https://doi.org/10.1080/10549811.2018.1478309

Melhorança, A. (1984). Efeito dos herbicidas pós-emergentes no desenvolvimento e na produção de grãos de soja. Londrina: Embrapa.

Nicolai, M., López Ovejero, R. F., Carvalho, S. J. P., Moreira, M. S., \& Christoffoleti, P. J. (2006). Effects of cover nitrogen fertilization on herbicide selectivity in corn. Planta Daninha, 24, 279-286. https://doi.org/ $10.1590 / \mathrm{S} 0100-83582006000200010$

Peixoto, C. M., \& Ramos, A. A. (2002). Milho: Manejo de herbicida, Caderno técnico (Cultivar Grandes Culturas, No. 42). Pelotas, Brazil.

Peregoy, R. S., Kitchen, L. M., Jordan, P. W., \& Griffin, J. L. (1990). Moisture stress effects on the absorption, translocation, and metabolism of haloxyfop in johnsongrass (Sorghum halepense) and large crabgrass (Digitaria sanguinalis). Weed Science, 38, 331-337. https://doi.org/10.1017/S0043174500056630

Peterson, D. E., Shoup, D. E., Thompson, C. R., \& Jugulam, M. (2015). Herbicide Mode of Action. Kansas: Kansas State University. Retrieved from https:/www.bookstore.ksre.ksu.edu/pubs/c715.pdf

Resende, A. V., Coelho, A. M., Santos, F. C., \& Lacerda, J. D. J. (2012). Fertilidade do solo e manejo da adubação NPK para alta produtividade de milho no Brasil Central. Embrapa Milho e Sorgo-Circular Técnica (INFOTECA-E, No 181).

Rodrigues, M. J., Turozi, T. A., Netto, A. P. C., \& Timossi, P. C. (2012). Épocas da adubação nitrogenada 
relacionada à aplicação de nicosulfuron na cultura do milho. Global Science and Technology, 5, 70-77.

Sønderskov, M., Swanton, C. J., \& Kudsk, P. (2012). Influence of nitrogen rate on the efficacy of herbicides with different modes of action. Weed Research, 52, 169-177. https://doi.org/10.1111/j.1365-3180.2012.00906.x

Souza, J. R. J. A. (2015). Interação da adubação nitrogenada e herbicidas no controle de plantas daninhas e seletividade na cultura do milho (Dissertação (Mestrado em Produção Vegetal), Universidade de Rio Verde, Rio Verde).

Spader, V., Antoniazzi, N., Luckmann, J. M., Makuch, E. I., \& Hilario, J. M. N. (2008). Seletividade de herbicidas pós emergentes em híbridos de milho. Congresso Brasileiro da Ciência das Plantas Daninhas, 26; Congreso de la Asociacion Latinoamericana de Malezas, 18, 2008, Ouro Preto. Anais... Sete Lagoas: SBCPD: Embrapa Milho e Sorgo.

Zanatta, F. S., Rizzardi, M. A., Lamb, T. D., \& Johann, L. B. (2007). Influência de doses de nitrogênio na época de controle de plantas daninhas na cultura do milho (Zea mays). Planta Daninha, 25, 529-536. https://doi.org/10.1590/S0100-83582007000300012

\section{Copyrights}

Copyright for this article is retained by the author(s), with first publication rights granted to the journal.

This is an open-access article distributed under the terms and conditions of the Creative Commons Attribution license (http://creativecommons.org/licenses/by/4.0/). 